\title{
DETERMINATION OF HEAVY METALS IN BLACK SEA MYTILUSGALLO PROVINCIALIS AND RAPANA VENOSA
}

\author{
Stancheva M., V. Ivanova, K. Peycheva \\ Department of Chemistry, Faculty of Pharmacy, Medical University of Varna
}

\begin{abstract}
Shellfish living in seas can accumulate heavy metals and thus serve as excellent passive biomonitors. Concentrations of arsenic (As), cadmium (Cd), mercury ( $\mathrm{Hg})$, lead ( $\mathrm{Pb})$ and manganese (Mn) in two kinds of shellfish, Rapana venosa and Mytilus galloprovincialis were determined. Samples were collected at three coastal sites along the Bulgarian Black Sea, including one mussel farm. Shellfish tissues were subjected to microwave-assisted acid digestion followed by appropriate atomic absorption spectrometry (AAS) (Flame AAS for Mn, Electrothermal AAS for $\mathrm{Cd}, \mathrm{Pb}$ and As). Concentration of total mercury was determined by Direct Mercury Analyzer. Levels of metals varied within species. The results clearly indicated that the concentrations of As exceeded the maximum permissible levels (MLPs) of $2,0 \mathrm{mg} / \mathrm{kg}$ according to the Bulgarian Food Codex (2004).
\end{abstract}

Key words: heavy metals, atomic absorption spectrometry, Rapana venosa, Mytilus galloprovincialis, Bulgarian Black Sea

\section{INTRODUCTION}

Black Sea is the world's largest natural anoxic water basin below $180 \mathrm{~m}$ in depth. It is a closed sea with very high degree of isolation from the world's oceans, however, it receives freshwater inputs from some of the largest rivers in Europe such as the Danube, the Dniester, and the Dnieper $(12,13)$. Black Sea is considered as one of the most polluted seas, and recently increasing concentration of nutrients has led to a higher degree of eutrophication.

Heavy metal pollution of the marine environment has been long recognized as a serious environmental concern $(2,14)$. Marine organisms, especially shellfish, are capable of accumulating the metals from the environment in which they live. Heavy metals can be accumulated by marine organisms thought a variety of pathways (18). Over the last few decades the marine environment has been contaminated by persistent pollutants of agricultural and industrial origin. Heavy metal contamination has been identified as a concern in coastal environment, due to discharges from industrial waste, agricultural and urban sewage. Heavy metal levels are known to increase dramatically in marine environment mainly through anthropogenic activities. Shellfishes are good indicators of the long term monitoring of metal accumulation in the marine environment.

There are scanty data about heavy metal pollution in shellfish from the Bulgarian Black Sea coast for the last twenty years. The aim of this study was to determine the levels of

\footnotetext{
Address for correspondence

V. Ivanova, Dept. of Chemistry, Faculty of Pharmacy, Medical University of Varna, 55 Marin Drinov Str., 9002, Varna, Bulgaria phone: +359887807998

e-mail: veselina.ivanova@hotmail.com
}

lead $(\mathrm{Pb})$, cadmium $(\mathrm{Cd})$, arsenic $(\mathrm{As})$, mercury $(\mathrm{Hg})$ and manganese (Mn) in Black Sea mussel (Mytilus galloprovincialis) and rapana (Rapana venosa).

\section{MATERIAL AND METHODS}

Black mussel (Mytilus galloprovincialis) is a natural biofilter that inhabits tidal areas attached to rocks. Rapana venosa is a predatory sea snail that has entered the Black Sea in the middle of the last century and feeds mainly on black mussels.

\section{Sampling}

Shellfish samples were obtained at three sites along Bulgarian Black Sea coast such as Varna, Kranevo (shellfish farm) and Krapetz in spring 2011. The collected mollusks were depurated in filtered seawater for approximately $24 \mathrm{~h}$ before being transported to the laboratory with ice freezing. The soft tissues of mollusks were excised by stainless steel scalpel blades and then thoroughly rinsed with Milli-Q water to remove extraneous impurities. Total soft shellfish tissue was taken for analysis. After sufficient homogenation by a blender, the samples were kept at $-18^{\circ} \mathrm{C}$ until analysis. Special care was taken to prevent metal contamination of the samples by the laboratory equipment.

\section{Analytical procedure}

All the solutions were prepared with analytical reagent grade chemicals and ultra-pure water $(18 \mathrm{M} \Omega \mathrm{cm})$ was used for all of them. $\mathrm{HNO}_{3}$ of superb quality was purchased from Fluka. All the plastic and glassware were cleaned by soaking in $2 \mathrm{M} \mathrm{HNO}_{3}$ for $48 \mathrm{~h}$. They were rinsed five times with distilled water and then five times with deionised water prior to use. Stock standard solutions of As, $\mathrm{Hg}, \mathrm{Cd}, \mathrm{Mn}$ 
and $\mathrm{Pb}\left(1000 \mathrm{Mg} \mathrm{mL}^{-1}\right.$ Titrisol, Merck in $\left.2 \% \mathrm{v} / \mathrm{v} \mathrm{HNO}_{3}\right)$ were used for preparation of calibration standards.

Shellfish tissues were dissected and thoroughly washed with MQ water. To assess the total metal contents, microwave-assisted acid digestion procedure was carried out. Microwave digestion system 'Multiwave', 'Anton Paar' delivering a maximum power and temperature of $1000 \mathrm{~W}$ and $300^{\circ} \mathrm{C}$, respectively, and internal temperature control was used. Reactors were subjected to microwave energy at $800 \mathrm{~W}$ in five stages program. Determination of Mn was performed by flame atomic absorption spectrometry on a Perkin Elmer Zeeman $1100 \mathrm{~B}$ spectrometer with an air/acetylene flame. The instrumental parameters were optimized in order to obtain maximum signal-to-noise ratio. $\mathrm{As}, \mathrm{Cd}$ and $\mathrm{Pb}$ were estimated by electrothermal atomic absorption spectrometry on a Perkin Elmer Zeeman 3030 spectrometer with an HGA-600 atomizer. Pyrolytic graphite-coated graphite tubes with integrated platforms were used as atomizers. $\mathrm{Pd}$ as $\left(\mathrm{NH}_{4}\right)_{2} \mathrm{PdCl}_{4}$ was used as modifier for ETAAS measurements of As and $\mathrm{Cd}$. Total mercury was determined by Milestone Direct Mercury Analyzer DMA-80. Samples were analyzed in triplicate. All the data were subjected to a statistical analysis. Student's $t$-test was applied to estimate the significance of values.

\section{RESULTS AND DISCUSSION}

Concentrations were expressed in $\mathrm{mg} / \mathrm{kg}$ wet weight $(\mathrm{mg} / \mathrm{kg}$ w.w.). The experimental concentrations are summarized in Table 1 given as mean $\pm \mathrm{SD}$.
The Joint FAO/WHO (2004) Expert Committee on Food Additives establishes a provisional tolerable weekly intake (PTWI) for $\mathrm{Pb}$ as $0,025 \mathrm{mg} / \mathrm{kg}$ body weight (7). European Community and Bulgarian Food Codex set maximum permitted level for $\mathrm{Pb}$ in shellfish of $1,5 \mathrm{mg} / \mathrm{kg}$ w.w. $(4,10) . \mathrm{Pb}$ concentration in shellfish samples is shown on Fig. 1. It is highest in Rapana venosa from Krapetz - of $0,32 \mathrm{mg} / \mathrm{kg}$ w.w. The values obtained from the analyzed samples were below those reported in the literature available and below the standard established by various health organizations.

\section{Cadmium}

Occupational $\mathrm{Cd}$ exposure levels prove to be a risk factor for chronic lung disease and testicular degeneration. Cadmium could originate from water, sediments and food. It may accumulate in the human body and induce kidney dysfunction, skeletal damage and reproductive deficiency (1).

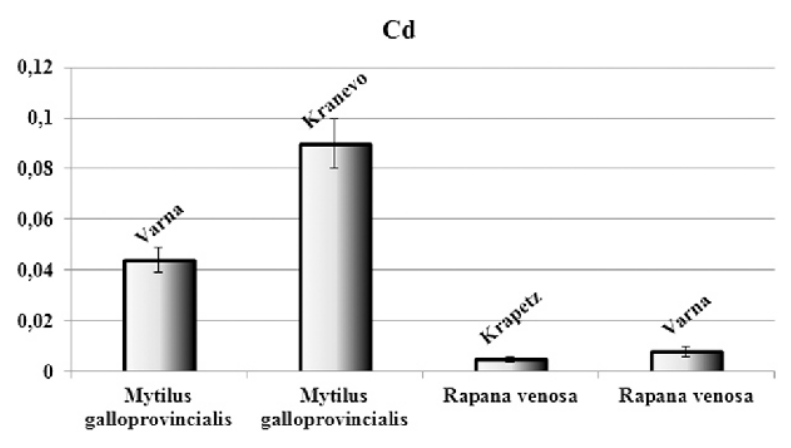

Fig. 2. Cd concentrations in shellfish samples

Table 1. Trace elements in shellfish (mean $\pm S D$ ) in $\mathrm{mg} / \mathrm{kg}$ w.w.

\begin{tabular}{||l|c|c|c|c|c|c||}
\hline \hline Sample & Sampling site & Mn & As & Cd & Pb & Hg \\
\hline Rapana venosa & Krapetz & $0,26 \pm 0,02$ & $4,17 \pm 0,37$ & $0,005 \pm 0,001$ & $0,32 \pm 0,03$ & $0,11 \pm 0,02$ \\
\hline Rapana venosa & Varna & $0,48 \pm 0,04$ & $2,20 \pm 0,20$ & $0,008 \pm 0,002$ & $0,12 \pm 0,01$ & $0,08 \pm 0,01$ \\
\hline Mytilus galloprovincialis & Varna & $1,24 \pm 0,10$ & $2,70 \pm 0,24$ & $0,044 \pm 0,005$ & $0,11 \pm 0,01$ & $0,08 \pm 0,01$ \\
\hline Mytilus galloprovincialis & Kranevo (shellfish farm) & $1,74 \pm 0,14$ & $2,07 \pm 0,19$ & $0,090 \pm 0,01$ & $0,18 \pm 0,01$ & $0,32 \pm 0,02$ \\
\hline \hline
\end{tabular}

\section{Lead}

Lead is toxic to humans, with the most deleterious effects on the hemopoietic, nervous, reproductive systems and the urinary tract.

$\mathrm{Pb}$

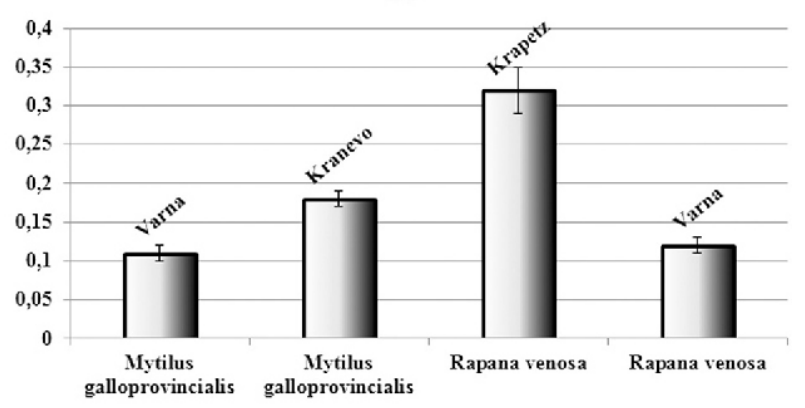

Fig. 1. Pb concentrations in shellfish samples
The highest $\mathrm{Cd}$ concentration $(0,09 \pm 0,01 \mathrm{mg} / \mathrm{kg}$ w.w. $)$ was obtained for Mytilus galloprovincialis from Kranevo (Fig. 2) while the lowest values were detected in Rapana venosa from Krapetz $(0,005 \pm 0,001 \mathrm{mg} / \mathrm{kg}$ w.w.). The European Community (4) established the maximum levels permitted for cadmium in shellfish as $1,0 \mathrm{mg} / \mathrm{kg}$ w.w. Moreover, the Joint FAO/WHO has recommended the provisional tolerable weekly intake (PTWI) for Cd of 0,007 mg/kg b. w. (7).

\section{Arsenic}

Arsenic, a naturally occurring element, is a worldwide contaminant that is found in rock, soil, water, air and food. Arsenic is a highly toxic element. It is present in inorganic and organic forms. Chronic exposure to inorganic As may cause severe damage in the peripheral and central nervous system. Humans can be exposed to As through the intake of 
food and drinking water, however, for most people, the major exposure source is the diet, mainly fish and seafood (3). A long-term As exposure has been related to some types of cancer. In this study, As concentration ranged from

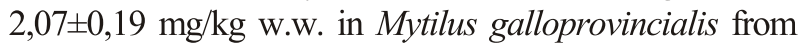

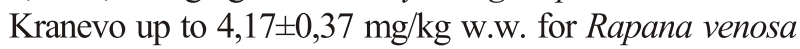
from Krapetz (Fig. 3).

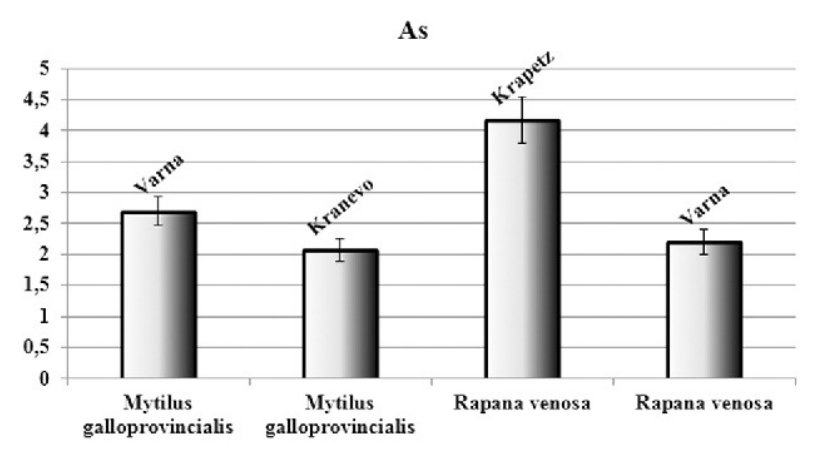

Fig. 3. As concentrations in shellfish samples

There are limited data about As content in shellfish species in the literature available. All the results obtained exceeded the maximum As level permitted for shellfish according to the Bulgarian Food Codex (of 2,0 mg $/ \mathrm{kg}$ w.w. (10).

\section{Mercury}

Mercury is toxic to the developing fetus and considered a possible carcinogen. The primary $\mathrm{Hg}$ source in human diet is seafood (5). Our results demonstrated that $\mathrm{Hg}$ concentration range was $0,08-0,32 \mathrm{mg} / \mathrm{kg}$ w.w. (Fig. 4).

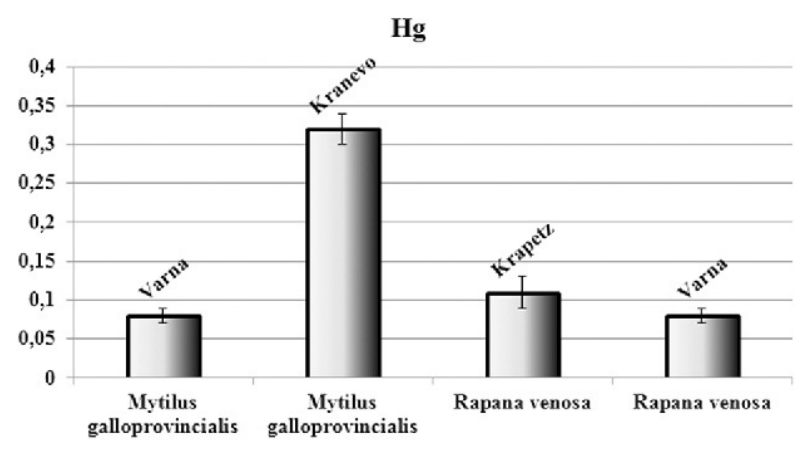

Fig. 4. Hg concentrations in shellfish samples

Mytilus galloprovincialis from shellfish farm showed the highest concentration of $0,32 \pm 0,02 \mathrm{mg} / \mathrm{kg}$ w.w. According to the Bulgarian Food Codex and European Community, the maximum $\mathrm{Hg}$ level permitted for shellfish is $0,5 \mathrm{mg} / \mathrm{kg}$ w.w. $(4,10)$. Hg levels in the analyzed samples were lower than legal limits.

\section{Manganese}

Manganese is a mineral element that is both nutritionally essential and potentially toxic. Mn plays an important role in a number of physiologic processes as a constituent of multiple enzymes and an activator of other enzymes. Nu- merous Mn-activated enzymes play important roles in the metabolism of carbohydrates, amino acids, and cholesterol. In humans, demonstration of a $\mathrm{Mn}$ deficiency syndrome is insufficiently clarified yet. Such signs include impaired growth and reproductive function, skeletal abnormalities, as well as altered carbohydrate and lipid metabolism (8). Dairy products, meat, fish, and poultry are among the richest dietary Mn sources (11). The minimum and maximum Mn levels observed were $0,26 \mathrm{mg} / \mathrm{kg}$ w.w. in Rapana venosa from Krapetz and 1,74 mg/kg w.w. in Mytilus galloprovincialis from Kranevo mussel farm (Fig. 5).

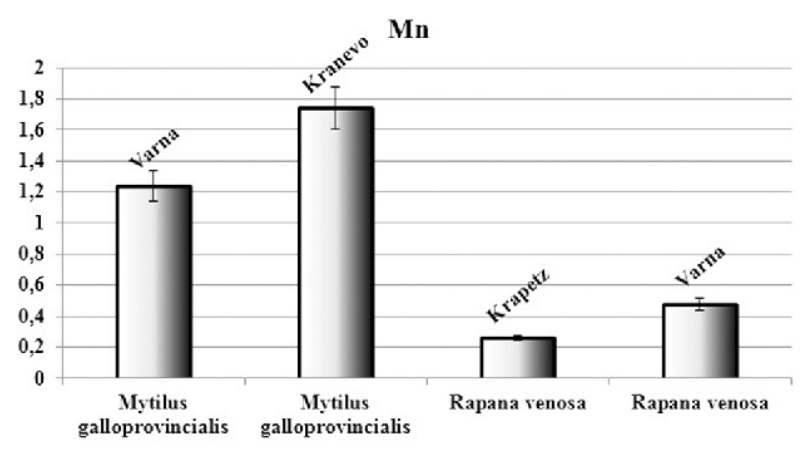

Fig. 5. Mn concentrations in shellfish samples

According to both FAO (6) and Bulgarian standards (10), there is no information about Mn carcinogenicity. The US National Academy of Science (15) recommended Mn of 2,5-5 mg daily and the World Health Organization recommended Mn of 2-9 mg daily for an adult individual (17). Concerning this RDA, Mn intake in our samples is below the above values.

As a whole, $\mathrm{Cd}, \mathrm{Hg}$ and $\mathrm{Mn}$ are established in highest concentrations in Mytilus galloprovincialis from Kranevo mussel farm, while $\mathrm{As}$ and $\mathrm{Pb}$ - in Rapana venosa from Krapetz. There is limited information about the heavy metal content in marine shellfish from the Black Sea. The results obtained in this study are, generally, in agreement with or lower than those reported in literature for mussels and rapana from the Black Sea (9) and other seas (16).

\section{CONCLUSIONS}

$\mathrm{Pb}, \mathrm{Cd}, \mathrm{Hg}$ and $\mathrm{As}$ accumulate in marine organisms and are subject to control in seafood. In this paper, the concentrations of five heavy metals are estimated in two kinds of shellfish such as Rapana venosa and Mytilus galloprovincialis. They are in the range: $0,11-0,32 \mathrm{mg} / \mathrm{kg}$ w.w. for $\mathrm{Pb} ; 0,005-0,044 \mathrm{mg} / \mathrm{kg}$ w.w. for $\mathrm{Cd} ; 0,08-0,32$ $\mathrm{mg} / \mathrm{kg}$ w.w. for $\mathrm{Hg} ; 2,07-4,17 \mathrm{mg} / \mathrm{kg}$ w.w. for As, and $0,26-1,74 \mathrm{mg} / \mathrm{kg}$ w.w. for $\mathrm{Mn}$. All the analyzed elements are within maximum permitted levels established by various health organizations, except for As, which exceeds the maximum permissible level of 2,0 $\mathrm{mg} / \mathrm{kg}$ w.w. (according to the Bulgarian Food Codex) (1). 


\section{Acknowledgements}

The authors would like to thank the National Science Fund, Ministry of Education and Science of Bulgaria for their financial support (Project DVU440/2008).

\section{REFERENCES}

1. Benoff, S., A. Jacops, I. R. Hurley. Male infertility and environmental exposure to lead and cadmium.- Hum. Reprod. Update, 6, 2000, No 2, 107-121.

2. Blakas, I. T., S. Tugrul, I. Salihoglu. Trace metal levels in fish and crustacea from Northeastern Mediterranean coastal waters.- Marine Env. Res., 6 , 1982, No 4, 281-289.

3. Castro-Gonzales, M. I., M. Méndez-Armenta. Heavy metals: implication associated to fish consumption.- Env. Toxicol. Pharmacol., 26, 2008, No 3, 263-271.

4. Commission Regulation (EC) No 1881/2006.- Offic. J. Eur. Union, 20.XII.2006.

5. Emami Khansari, F., M. Ghazi-Khansari, M. Abdollahi. Heavy metals content of canned tuna fish.- Food Chem., 93, 2005, 293-296.

6. FAO. Compilation of legal limits for hazardous substances in fish and fishery products. FAO Fishery Circular No464, 5-10 Food and Agricultural Organization of the United Nations. Rome, 1989.

7. FAO/WHO. Summary of Evaluations Performed by the Joint FAO/WHO Expert Committee on Food Additives (JECFA 1956-2003). ILSI Press International Life Sciences Institute, 2004.

8. http://lpi.oregonstate.edu/infocenter/minerals/manganese/

9. Namesnik, J., P. Szefer, M. Sliwka-Kaszynska, S. Moncheva, P. Arancibia-Avila, F. Toledo, et al. Determina- tion of PAHs, PCBs, minerals, trace elements, and fatty acids in Rapana thomasiana as an indication of pollution.- J. AOAC Int., 93, 2010, No 5, 1600-1608.

10. Ordinance No 31 about the maximally permissible quantities of food pollutants. Sofia, Official gazette No 88, 2004 (in Bulgarian).

11. RDA. Recommended Dietary Allowances. $10^{\text {th }}$ ed. Washington, D.C., National Academy Press, 1989.

12. Stancheva, M., K. Peycheva, L. Makedonski, T. Rizov. Heavy metals and PCBs level of bluefish (Pomatomus saltatrix) from Bulgarian Black sea waters.- Ovidius Univ. Ann. Chem., 21, 2010, No 1, 41-48.

13. Stoichev, T., L. Makedonski, T. Trifonova, M. Stancheva, F. Ribarova. DDT in fish from the Bulgarian region of the Black Sea.- Chem. Ecol., 23, 2007, No 3, 191-200.

14. Tariq, J., M. Jaffar, M. Moazzam. Concentration correlations between major cations and heavy metals in fish from the Arabian Sea.- Marine Pollut. Bull., 22, 1991, No 11, 562-565.

15. United States Environmental Protection Agency. Methods for chemical analysis of water and waste. EPA report 600/4-79-020. Cincinnati, OH, Office of Water, 1983.

16. Wang, Y., L. Liang, J. Shi, G. Jiang. Study on the contamination of heavy metals and their correlations in mollusks collected from coastal sites along the Chinese Bohai Sea.- Env. Int., 31, 2005, No 8, 1103-1113.

17. WHO. Quality Directive of Portable Water. $2^{\text {nd }}$ ed. Geneva, WHO, 31, 1994, 197.

18. Zhou, J. L., S. M. Salavador, Y. P. Liu, M. Sequeria. Heavy metals in the tissues of common dolphins (Delphinus delphis) stranded on the Portuguese coast.- Sci. Total Env., 273, 2001, No 1-3, 61-76. 